\title{
Ictal multicomponent agraphia in left temporal lobe epilepsy
}

Carol Ulloa, MD, Gloria Ortiz-Guerrero, MD, Caleb Pearson, PhD, John Leever, MD, Patrick Landazuri, MD, and Utku Uysal, MD

Neurology ${ }^{\circledR}$ 2020;94:42-43. doi:10.1212/WNL.0000000000008705
Correspondence

Dr. Ulloa

culloa@kumc.edu

Figure 1 Illustration

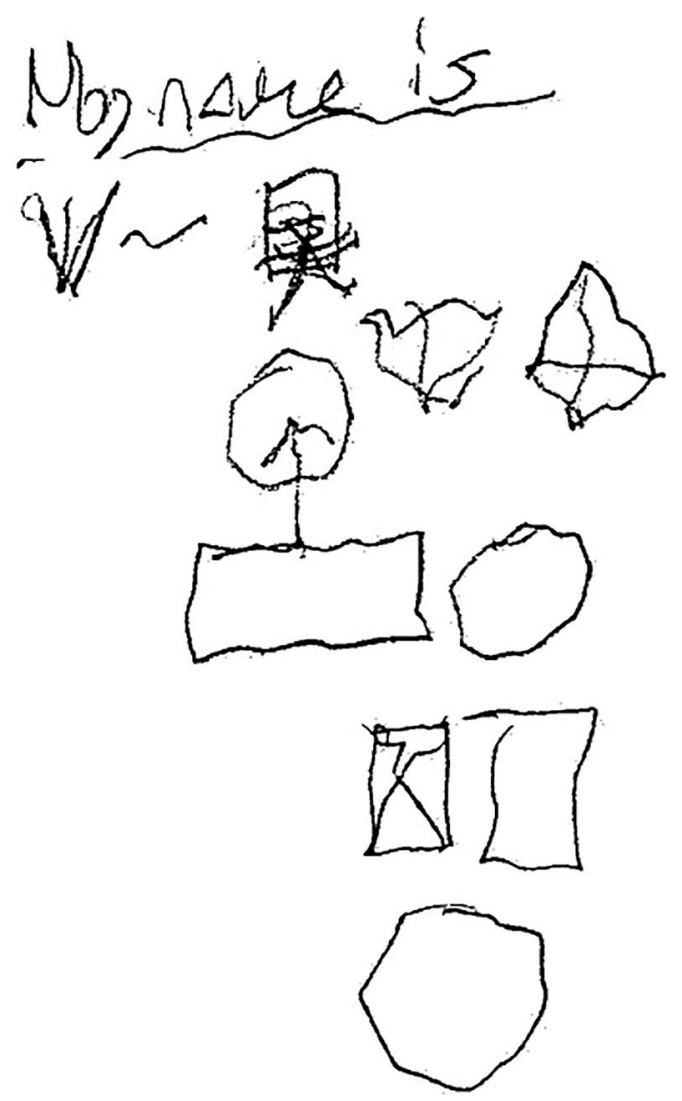

According to the patient, "Couldn't think of letters to write-just shapes to start."

A 58-year-old woman with a clinical diagnosis of temporal lobe epilepsy characterized by episodes of disorientation and derealization followed by aphasia tried to write sentences during a seizure. Instead, she drew random figures (figure 1). External standard MRI was reported normal; however, a nonenhancing left amygdala lesion was identified on our 3T epilepsy protocol MRI (figure 2). This drawing emphasizes ictal multicomponent agraphia characterized by impaired allographic storage with expected accompanying aphasia. ${ }^{1} \mathrm{Al}$ though symbolic graphic language is impaired, non-language-based symbolic graphic production remains intact. This suggests posterior temporal/temporo-parietal junction involvement during seizure spread. ${ }^{2}$ 


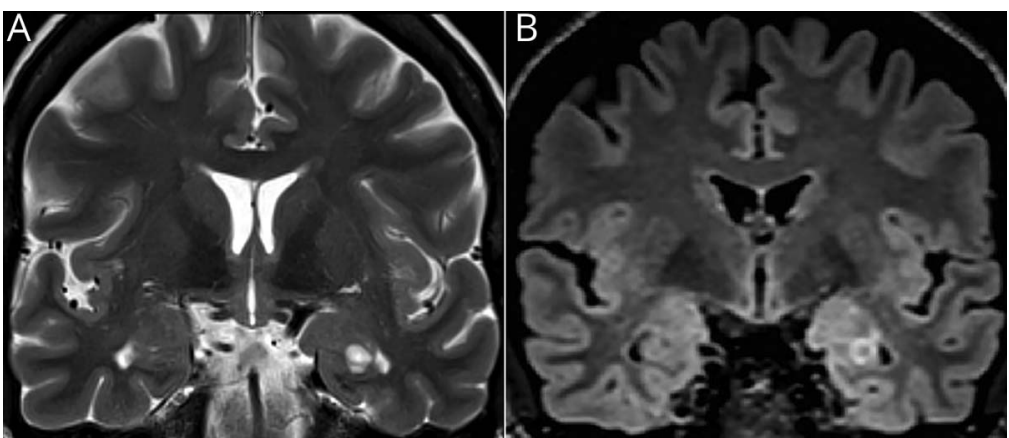

Coronal T2 (A) and fluid-attenuated inversion recovery (FLAIR) (B) MRI. Ovoid lesion with FLAIR hyperintense rim in left amygdala. Characteristics are typical of dysembryoplastic neuroepithelial tumor, a cystic "bubbly" intracortical tumor that often involves the temporal lobe. Ganglioglioma also commonly arises in the temporal lobes but may exhibit enhancement and calcification.

\section{Study funding}

No targeted funding reported.

\section{Disclosure}

The authors report no disclosures relevant to the manuscript. Go to Neurology.org/N for full disclosures.

\section{Appendix Authors}

\begin{tabular}{|c|c|c|c|}
\hline Name & Location & Role & Contribution \\
\hline $\begin{array}{l}\text { Carol } \\
\text { Ulloa, MD }\end{array}$ & $\begin{array}{l}\text { University of } \\
\text { Kansas } \\
\text { Medical } \\
\text { Center }\end{array}$ & Author & $\begin{array}{l}\text { Conceptualized the } \\
\text { manuscript, treating } \\
\text { physician, prepared the } \\
\text { manuscript }\end{array}$ \\
\hline $\begin{array}{l}\text { Gloria } \\
\text { Ortiz- } \\
\text { Guerrero, } \\
\text { MD }\end{array}$ & $\begin{array}{l}\text { University of } \\
\text { Kansas Medical } \\
\text { Center }\end{array}$ & Author & $\begin{array}{l}\text { Assisted in writing the } \\
\text { manuscript, technical editing } \\
\text { of the images }\end{array}$ \\
\hline $\begin{array}{l}\text { Caleb } \\
\text { Pearson, } \\
\text { PhD }\end{array}$ & $\begin{array}{l}\text { University of } \\
\text { Kansas } \\
\text { Medical } \\
\text { Center }\end{array}$ & Author & $\begin{array}{l}\text { Analyzed the functional } \\
\text { anatomy related to the } \\
\text { patient's drawing, edited the } \\
\text { illustration legend }\end{array}$ \\
\hline
\end{tabular}

\begin{tabular}{llll} 
Appendix & (continued) & & \\
\hline Name & Location & Role & Contribution \\
\hline $\begin{array}{l}\text { John } \\
\text { Leever, MD }\end{array}$ & $\begin{array}{l}\text { University of } \\
\text { Kansas } \\
\text { Medical } \\
\text { Center }\end{array}$ & Author & $\begin{array}{l}\text { Interpreted the MRI, edited } \\
\text { the figure legend }\end{array}$ \\
\hline $\begin{array}{l}\text { Patrick } \\
\text { Landazuri, } \\
\text { MD }\end{array}$ & $\begin{array}{l}\text { University of } \\
\text { Kansas } \\
\text { Medical } \\
\text { Center }\end{array}$ & Author & $\begin{array}{l}\text { Revised the manuscript for } \\
\text { intellectual content }\end{array}$ \\
\hline $\begin{array}{l}\text { Utku } \\
\text { Uysal, MD }\end{array}$ & $\begin{array}{l}\text { University of } \\
\text { Kansas } \\
\text { Medical } \\
\text { Center }\end{array}$ & Author & $\begin{array}{l}\text { Revised the manuscript for } \\
\text { intellectual content }\end{array}$ \\
& & & \\
\hline
\end{tabular}

\section{References}

1. Heilman KM, Valenstein E. Clinical Neuropsychology, 5th ed. New York: Oxford University Press; 2011.

2. Baldo JV, Kacinik N, Ludy C, et al. Voxel-based lesion analysis of brain regions underlying reading and writing. Neuropsychologia 2018;115:51-59.

\section{Share Your Artistic Expressions in Neurology 'Visions'}

AAN members are urged to submit medically or scientifically related artistic images, such as photographs, photomicrographs, and paintings, to the "Visions" section of Neurology $y^{\circ}$. These images are creative in nature, rather than the medically instructive images published in the NeuroImages section. The image or series of up to six images may be black and white or color and must fit into one published journal page. Accompanying description should be 100 words or less; the title should be a maximum of 96 characters including spaces and punctuation.

Please access the Author Center at NPub.org/authors for full submission information. 


\section{Neurology}

\section{Ictal multicomponent agraphia in left temporal lobe epilepsy}

Carol Ulloa, Gloria Ortiz-Guerrero, Caleb Pearson, et al.

Neurology 2020;94;42-43

DOI 10.1212/WNL.0000000000008705

This information is current as of December 30, 2019

$\begin{array}{ll}\begin{array}{l}\text { Updated Information \& } \\ \text { Services }\end{array} & \begin{array}{l}\text { including high resolution figures, can be found at: } \\ \text { http://n.neurology.org/content/94/1/42.full }\end{array} \\ \text { References } & \text { This article cites } 1 \text { articles, } 0 \text { of which you can access for free at: } \\ & \text { http://n.neurology.org/content/94/1/42.full\#ref-list-1 } \\ \text { Subspecialty Collections } & \text { This article, along with others on similar topics, appears in the } \\ & \text { following collection(s): } \\ & \text { All Epilepsy/Seizures } \\ \text { http://n.neurology.org/cgi/collection/all_epilepsy_seizures } & \text { Epilepsy semiology } \\ \text { http://n.neurology.org/cgi/collection/epilepsy_semiology } \\ \text { Epileptogenic zone } \\ \text { http://n.neurology.org/cgi/collection/epileptogenic_zone } \\ & \text { Information about reproducing this article in parts (figures,tables) or in } \\ & \text { its entirety can be found online at: } \\ \text { http://www.neurology.org/about/about_the_journal\#permissions } & \text { Information about ordering reprints can be found online: } \\ \text { http://n.neurology.org/subscribers/advertise }\end{array}$

Neurology ${ }^{\circledR}$ is the official journal of the American Academy of Neurology. Published continuously since 1951, it is now a weekly with 48 issues per year. Copyright @ 2019 American Academy of Neurology. All rights reserved. Print ISSN: 0028-3878. Online ISSN: 1526-632X.

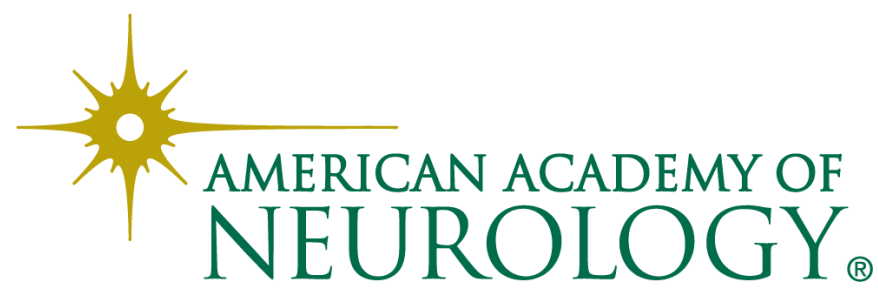

